\title{
Topical hemostatics for bleeding control in pre-hospital setting: Then and now
}

\author{
H. Erhan Güven, M.D.
}

Department of General Surgery, University of Health Sciences Gülhane Training and Research Hospital, Ankara-Turkey

\begin{abstract}
Massive hemorrhage causes instant and early deaths because of hypovolemia. However, even if the victim makes it to the hospital, hypothermia, metabolic acidosis, and coagulation impairments caused by bleeding pose a great risk for survival. Many topical hemostatic agents are developed for neck, armpit, or groin injuries that are not amenable to tourniquet application and for extremity wounds to be used in conjunction with tourniquets. This paper focuses on those hemostatics that differ based on the action mechanism and are suitable for pre-hospital setting and summarizes the latest recommendations regarding their usage.
\end{abstract}

Keywords: Bleeding; pre-hospital; topical hemostatics.

\section{INTRODUCTION}

Every bleeding eventually stops. However this fact gives no relief to any surgeon in the operating room or medical personnel on the field dealing with hemorrhage. Bleeding causes death not only from hypovolemia and exsanguination at the scene but also from uncorrectable metabolic acidosis, hypothermia, multiple organ failure, and coagulation disorders that are resistant to transfusions even after the victim is hospitalized.

The latest data on this topic is derived from US combat soldiers wounded during the Iraq and Afghanistan campaigns between $200 \mathrm{I}$ and $20 \mathrm{II}$, which show that $24 \%$ of deaths were seemingly potentially survivable and $90 \%$ of them were related to hemorrhage. Among the injuries that caused death, $67.3 \%$ were truncal, $19.2 \%$ were junctional (neck, axilla, and inguinal regions), and $13.5 \%$ were located on the extremities. ${ }^{[1,2]}$ This data reveals the paramount importance of hemor-

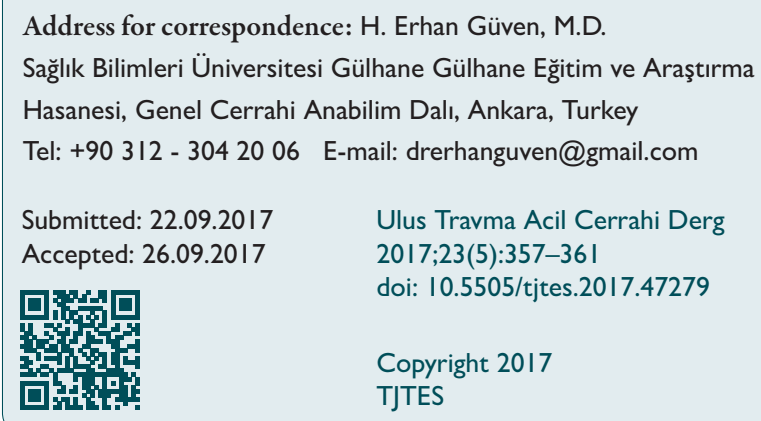

rhage control to save lives with proper scientific and technical measures. Topically applied hemostatic agents mainly aim to help those with junctional hemorrhage because they are not suitable for tourniquet application, such as extremity wounds. However, they can also be used along with tourniquets in extremity wounds.

In a review by Sobrino et al., it is stated that the consequences of trauma in a civilian setting are fundamentally the same. Hemorrhage is the second leading cause of death after traumatic brain injury in immediate and early phases of trauma. ${ }^{[3]}$ With increasing occurrence of terrorist attacks globally, it will not be surprising to experience a constant rise in exsanguination incidence among civilian mass casualties.

Moreover, one should always keep in mind that in the battlefield, rural areas, and wilderness, the so called pre-hospital setting, the first responder to hemorrhage is almost always a non-medical personnel: a friend (so called a "buddy") on the battlefield, a local resident, or a companion. Thus, the first intervention should be called an "attempt to control bleeding" rather than "hemostasis."

Topical hemostatics are also important for trauma victims who can make it to a medical facility. Intracorporeal topical hemostatics are used in emergency surgery for trauma, such as to control initial damage and stop bleeding from liver or major vessels. Although some agents mentioned below have also been used for intracorporeal hemostasis with great success, the evaluation criteria of topical hemostatic agents are different from this paper's vantage point. 


\section{Physiological Hemostasis}

Let me provide some information on clot formation prior to the discussion on hemostasis. One of the most dynamic system of concurrent production (clotting) and destruction (fibrinolysis) in vivo is the coagulation system. The basic concept of coagulation has not changed after the introduction of the "cascade" system by MacFarlane in 1964. ${ }^{[4]}$ Reflex vasoconstriction occurs first under the influence of local mediators. Von Willebrand factor and glycoproteins lock each other to start thrombocyte adhesion. Secretion continues from the thrombocytes leading to further adhesion and aggregation. Activated by subendothelial tissue factor, the extrinsic pathway proceeds to convert factor $X$ to its active form. Factor XII triggers another route, intrinsic pathway that ends up at the same step where active factor $X$ is formed. The common pathway moves forward to the final destination where a stable clot is formed. Homeostasis of hemostasis continues with the fibrinolytic events that terminate the clot after it is no longer needed. ${ }^{[5]}$

\section{Topical Hemostatic Agents}

With this proximate knowledge about the clotting process, it is practical to classify topical hemostatics according to their action mechanism into three categories:

I) Coagulation factor and thrombocyte concentrators

2) Mucoadhesive agents or physical sealants

3) Coagulation cascade activators that either supply some key proteins of the system or trigger the system

\section{Zeolite}

As an easy-to-find natural mineral, zeolite can be considered as the prototype of concentrator agents. Its porous structure allows rapid adsorption of water, which increases the relative concentration of coagulation factors and thrombocytes at the bleeding site where clotting process takes place. Adsorption is an exothermic reaction that gives off heat.

In a study with zeolite's early commercial form, QuikClot ${ }^{\circledR}$ bleeding was controlled in $92 \%$ of patients. However, the heat generated during the application caused pain in one-fourth of the patients and three burns were encountered (Table I). ${ }^{[6]}$ Aiming to reduce the heat effect of zeolite, QuikClot ACS $^{\circledR}$ was introduced in the market. In their animal model study, Eryilmaz et al. concluded that QuikClot ACS $^{\circledR}$ decreased the amount of bleeding but could not completely stop it in any of the test subject. Furthermore, they observed cellular changes caused by heat generation reaching up to $80^{\circ} \mathrm{C} \cdot{ }^{[7]}$ The successor of these two products was QuikClot ACS ${ }^{\circledR}$. Hydrated zeolites were packed in porous meshes to minimize heat problem. This was accomplished at a cost of decreased hemostatic efficacy, discrediting the product for combat scenarios. ${ }^{[8,9]}$

Clinoptilolite, a type of zeolite mineral, was tested for the first time by Bayır et al. and was found to be as effective as kaolin, which will be discussed below, without inducing any temperature rise. ${ }^{[10]} \mathrm{New}$ research on other zeolite minerals should be encouraged as zeolite-based topical hemostatics are easy to produce with low cost.

\section{Starch Derivatives}

Belonging to this group, TraumaDex ${ }^{\circledR}$ contains microporous polysaccharide hemospheres and BleedArrest ${ }^{\circledR}$ contains amylopectin. Both are derived from potato starch and are found to be successful concentrators but are not applicable on battlefields. ${ }^{\left[{ }^{\prime \prime}\right]}$

\section{Chitosan}

Chitin is the main polysaccharide found in the exoskeleton of invertebrates and shells of crustaceans (such as crab, shrimp, lobster, etc.). Chitosan is produced by the deacetylation of chitin and is the center of attraction for a series of biomedical investigations on obesity, fungal infestations, and bacterial infections, as well as hemorrhage. ${ }^{[12,13]}$ Chitosan's positively charged surface successfully attracts erythrocytes and mechanically seals the bleeding site, and its chemical structure causes vasoconstriction, which enhances its hemostatic effect. ${ }^{[14,15]}$ HemCon Bandage ${ }^{\circledR}$, Celox ${ }^{\circledR}$, and ChitoGauze ${ }^{\circledR}$ are the best known commercial products containing chitosan as an active ingredient. Preclinical studies are the mainstay of using chitosan-based materials on the battlefield. ${ }^{[16]}$ It achieves hemostasis without requiring the integrity of the clotting system and without any heat problems in the tissue. ${ }^{[8,16]}$ Wedmore's study on 64 wounded soldiers reported that Hem$\mathrm{Con}^{\circledR}$ was successful in stopping or reducing the bleeding (Table I). ${ }^{[17]}$ Additional case reports and animal studies with Celox ${ }^{\circledR}$ and ChitoGauze ${ }^{\circledR}$ supported the former outcomes, and all the abovementioned products took their places in the guideline of the Committee on Tactical Combat Casualty Care (CoTCCC). ${ }^{[18]}$

A novel chitosan-based hemostatic product was introduced in 2014 and acquired U.S. Food and Drug Administration (FDA) approval. XStat ${ }^{\circledR}$ became the prototype of a new class of topical hemostatic agent/device: a non-absorbable, expandable, hemostatic sponge for internal use. ${ }^{[19]}$ The syringelike device consists of chitosan-coated mini-sponges that expand in contact with blood. It concentrates clotting factors and seals the bleeding site at the same time. Although not yet cleared for use above the clavicle line, in the thorax, and in the abdomen, this device is designed to help bleeding control in wounds with a narrow opening in junctional body parts and extremities. Its application is also restricted to patients who are expected to reach proper surgical care facility in no more than 4 hours. ${ }^{[20]}$

\section{Kaolin}

Kaolin is a clay rock that is rich in kaolinite. It has a polar surface with a slight negative charge that plays a key role in triggering the intrinsic pathway of the coagulation cascade, 
Table I. Three human studies on three commonly used topical hemostatic agents

\begin{tabular}{|c|c|c|c|c|}
\hline Study & $\begin{array}{l}\text { Topical } \\
\text { hemostatic } \\
\text { agent }\end{array}$ & $\begin{array}{l}\text { Number } \\
\text { of patients } \\
\text { (n) }\end{array}$ & Wound localization & Results \\
\hline Rhee et al. ${ }^{[6]}$ & $\begin{array}{l}\text { Quikclot } \\
\text { (zeolite) }\end{array}$ & 103 & $\begin{array}{l}\text { Head, scalp, and neck }(n=12) \\
\text { Extremities }(n=6 \mid) \\
\text { Chest and upper back }(n=16) \\
\text { Abdomen, lower back, and groin }(n=\mid 8) \\
\text { Intracorporeal }(n=20)\end{array}$ & $\begin{array}{l}\text { Overall efficacy rate, } 92 \% \\
\text { Efficacy in blast trauma, } 21 / 22 \\
\text { Efficacy in gunshot wounds, } 65 / 68 \\
\text { Efficacy in stab wounds, } 3 / 5 \\
\text { Mild-to-severe discomfort due to } \\
\text { heat produced by the material. } \\
\text { Three burn cases, one requiring } \\
\text { skin grafting } \\
\text { One foreign body reaction and scar } \\
\text { formation (in intracorporeal use) }\end{array}$ \\
\hline Wedmore et al. ${ }^{[17]}$ & $\begin{array}{l}\text { HemCon } \\
\text { (chitosan) }\end{array}$ & 64 & $\begin{array}{l}\text { Extremities }(n=35) \\
\text { Head and neck }(n=4) \\
\text { Others }(n=25)\end{array}$ & $\begin{array}{l}\text { Success rate, } 97 \% \\
\text { No complications or adverse } \\
\text { events reported }\end{array}$ \\
\hline Ran et al. ${ }^{[22]}$ & $\begin{array}{l}\text { Quikclot Combat } \\
\text { Gauze (kaolin) }\end{array}$ & 14 & $\begin{array}{l}\text { Extremities }(n=4) \\
\text { Others (head, neck, axilla, abdomen, } \\
\text { etc.) }(n=10)\end{array}$ & $\begin{array}{l}\text { Overall success rate, } 79 \% \\
\text { No complications or adverse } \\
\text { events reported }\end{array}$ \\
\hline
\end{tabular}

making it a member of the procoagulant class topical hemostatics. It is likely that kaolin acts by augmenting activation of factors XII and XI, as well as prekallikrein and high-molecular-weight kininogen. ${ }^{[8,21]}$ Recommended by CoTCCC since 2008, QuikClot Combat Gauze ${ }^{\circledR}$ was approved by FDA in 2013 for external use. Although the only study conducted on the field with soldiers by Ran et al. showed an efficacy of $79 \%$, after some animal studies, CoTCCC was confident that this product should be used in the first line of bleeding control attempt (Table I). ${ }^{[22-24]}$ The late onset of hemostatic effect and the need for an intact coagulation system without any factor deficiencies are the pitfalls of kaolin-based hemostatics. ${ }^{8]}$

\section{Smectite}

Woundstat ${ }^{\circledR}$, a commercial product containing smectite group clay, which has the ability to stop bleeding by simultaneously concentrating the clotting factors, initiating the intrinsic pathway, and sealing the wound, was cleared by FDA in 2007. ${ }^{[8,25]}$ When compared with others, it has proved its superiority as being the fastest and most effective product in animal studies. ${ }^{[26,27]}$ However, it induces transmural damage to the bleeding vessel, making it impossible to perform repair, and causes occluding thrombosis to the distal of the injury that compromises safety. ${ }^{[28]}$ In general, removal of a topical hemostatic during a definitive surgical intervention of hemorrhage, especially when it is in the granular form, has paramount importance. However, as an inert material, Woundstat $^{\circledR}$ was reported to adhere so tightly to the applied tissue that several attempts were needed for a complete removal. ${ }^{[27]}$
Because of these safety issues, it was permanently suspended by FDA in 2009. Woundstat ${ }^{\circledR}$ is a good example for "too good to be true" situation after all.

\section{Herbal Complex}

Urtica dioica, Vitis vinifera, Glycrrhiza glabra, Alpinia officinarum, and Thymus vulgaris are the ingredients of Ankaferd Bloodstopper ${ }^{\circledR}$. Its action mechanism is described in its information brochure. It acts independently from the clotting system via erythrocyte aggregation in a protein network environment. Pubmed search revealed few review studies mainly commenting on its efficacy during endoscopic interventions. [29-31] Recent studies on this product focus on growth inhibitory properties, germicidal effects against hydatid cyst, and acceleration of muscle healing in open fractures rather than its hemostatic activity. ${ }^{[32-34]}$

\section{Dry Fibrin Sealant Dressing}

This includes a subgroup of procoagulants as a supplier of clotting factors. It contains purified fibrinogen, thrombin, and factor XIII, as well as factor IV (calcium). Although it was found to be successful in its initial use on the battlefield, its cost and efficacy of cheaper products blocked its path. ${ }^{[14,27]}$

Topical hemostatics are always a focus of interest for research and development staff and scientists. New materials, such as polyurethane foam and hydrophobically modified alginate lyophilized sponge, as well as modification of the existing ones, such as two-layer gelatin, are under continuous 
investigations that will surely contribute to the war against war injuries. ${ }^{[35-38]}$

\section{DISCUSSION}

An ideal topical hemostatic agent to be used on a battlefield should be non-toxic, be able to control both arterial and venous hemorrhage, be ready to be used instantly, be easily applicable by the sufferer or a buddy, have a long shelf-life with copper-bottomed protection, be small in size and weight but durable in all extreme conditions in a haversack, be inexpensive and cost-effective, and perhaps be practical under night vision. ${ }^{[39,40]}$

It is equally important to develop topical hemostatics and quantify the comparison between them. A recent study proposes a novel methodology, which is in line with FDA's clinician-reported scale. If used, this validated bleeding severity scale will assure that all clinicians conducting studies on topical hemostatics are speaking the same language when it comes to comparing outcomes. ${ }^{[4]}$

Zeolite-based agents are most effective in their purest mineral form, but heat production is a major problem to limit their use. Hydration of the material reduces this side effect but it also compromised its efficacy. ${ }^{[6,8,9]}$ Although very successful in achieving bleeding control, smectite is outdated because of its potential for tissue damage and inability to wipe it off the tissue. ${ }^{[15,27]}$ Chitosan seems relatively safe; the only concern regarding its use may be shellfish allergy of the individual. [14,15] Kaolin is also safe but needs more time for achieving hemostasis and an intact coagulation system in the individual. [8] Dry fibrin sealants are expensive and fragile for battlefield environment. ${ }^{[14]}$

At this juncture, the latest revision of coTCCC Guidelines for Medical Personnel (April 16, 2017) advocates a kaolin-based agent in the first line and chitosan-based agents afterward to be used in conjunction with appropriate tourniquets. ${ }^{[2]}$

\section{Acknowledgments}

I cordially thank Mehmet Eryılmaz, M.D., for his support. I also thank the chairman and board members of the Turkish Association of Trauma and Emergency Surgery for their kind invitation for this paper. This work is derived from the original speech given by the author in the War Surgery session of the II th Turkish Congress of Trauma and Emergency Surgery held in April 2017.

\section{Conflict of Interest}

I do not have any financial or non-financial interest, membership, employment, consultancies, stock ownership, or patentlicensing arrangements in any of the products mentioned in this paper. The trademark names of products are used because all papers regarding topical hemostatic also mention them.

\section{REFERENCES}

1. Eastridge BJ, Mabry RL, Seguin P, Cantrell J, Tops T, Uribe P, et al. Death on the battlefield (2001-2011): implications for the future of combat casualty care. J Trauma Acute Care Surg 2012;73:S431-7. Erratum in: J Trauma Acute Care Surg. 2013;74:706. Kotwal, Russell S [corrected to Kotwal, Russ S]. [CrossRef]

2. Kotwal RS, Butler FK Jr. Junctional Hemorrhage Control for Tactical Combat Casualty Care. Wilderness Environ Med 2017;28:S33-8.

3. Sobrino J, Shafi S. Timing and causes of death after injuries. Proc (Bayl Univ Med Cent) 2013;26:120-3.

4. MacFarlane RG. An enzyme cascade in the blood clotting mechanism, and its function as a biochemical amplifier. Nature 1964;202:498-9.

5. Palta S, Saroa R, Palta A. Overview of the coagulation system. Indian J Anaesth 2014;58:515-23. [CrossRef]

6. Rhee P, Brown C, Martin M, Salim A, Plurad D, Green D, et al. QuikClot use in trauma for hemorrhage control: case series of 103 documented uses. J Trauma 2008;64:1093-9. [CrossRef]

7. Eryilmaz M, Ozer T, Menteş O, Torer N, Durusu M, Günal A, et al. Is the zeolite hemostatic agent beneficial in reducing blood loss during arterial injury? Ulus Travma Acil Cerrahi Derg 2009;15:7-11.

8. Pourshahrestani S, Zeimaran E, Djordjevic I, Kadri NA, Towler MR. Inorganic hemostats: The state-of-the-art and recent advances. Mater Sci Eng C Mater Biol Appl 2016;58:1255-68. [CrossRef]

9. Kheirabadi BS, Edens JW, Terrazas IB, Estep JS, Klemcke HG, Dubick MA, et al. Comparison of new hemostatic granules/powders with currently deployed hemostatic products in a lethal model of extremity arterial hemorrhage in swine. J Trauma 2009;66:316-26. [CrossRef]

10. Bayır A, Eryılmaz M, Demirbilek M, Denkbaş EB, Arzıman I, Durusu M. Comparison of the topical haemostatic efficacy of nano-micro particles of clinoptilolite and kaolin in a rat model of haemorrhagic injury. Eur J Trauma Emerg Surg 2016;42:77-86. Erratum in: Eur J Trauma Emerg Surg 2016;42:793. [CrossRef]

11. Burgert J, Gegel B, Neal AR, Kammer KE, Paul ME, Schwartz DJ, et al. The effects of arterial blood pressure on rebleeding when BleedArrest, Celox and TraumaDex are used in a porcine model of lethal femoral injury. Mil Med 2012;177:340-4. [CrossRef]

12. Jull AB, Ni Mhurchu C, Bennett DA, Dunshea-Mooij CA, Rodgers A. Chitosan for overweight or obesity. Cochrane Database Syst Rev 2008:CD003892. [CrossRef]

13. Verlee A, Mincke S, Stevens CV. Recent developments in antibacterial and antifungal chitosan and its derivatives. Carbohydr Polym 2017;164:268-83. [CrossRef]

14. Achneck HE, Sileshi B, Jamiolkowski RM, Albala DM, Shapiro ML, Lawson JH. A comprehensive review of topical hemostatic agents: efficacy and recommendations for use. Ann Surg 2010;251:217-28. [CrossRef]

15. Smith AH, Laird C, Porter K, Bloch M. Haemostatic dressings in prehospital care. Emerg Med J 2013;30:784-9. [CrossRef]

16. Bennett BL, Littlejohn L. Review of new topical hemostatic dressings for combat casualty care. Mil Med 2014;179:497-514. [CrossRef]

17. Wedmore I, McManus JG, Pusateri AE, Holcomb JB. A special report on the chitosan-based hemostatic dressing: experience in current combat operations. J Trauma 2006;60:655-8. [CrossRef]

18. Bennett BL. Bleeding Control Using Hemostatic Dressings: Lessons Learned. Wilderness Environ Med 2017;28:S39-49. [CrossRef]

19. De Novo Classification Request For Xstat. Available at: https://www. accessdata.fda.gov/cdrh_docs/reviews/K130218.pdf. Accessed Apr 16, 2017.

20. Sims K, Montgomery HR, Dituro P, Kheirabadi BS, Butler FK. Management of External Hemorrhage in Tactical Combat Casualty Care: The Adjunctive Use of XStat ${ }^{\mathrm{m}}$ Compressed Hemostatic Sponges: TCCC Guidelines Change 15-03. J Spec Oper Med 2016;16:19-28.

21. Gordy SD, Rhee P, Schreiber MA. Military applications of novel hemo- 
static devices. Expert Rev Med Devices 2011;8:41-7. [CrossRef]

22. Ran Y, Hadad E, Daher S, Ganor O, Kohn J, Yegorov Y, et al. QuikClot Combat Gauze use for hemorrhage control in military trauma: January 2009 Israel Defense Force experience in the Gaza Strip-a preliminary report of 14 cases. Prehosp Disaster Med 2010;25:584-8. [CrossRef]

23. Kheirabadi BS, Scherer MR, Estep JS, Dubick MA, Holcomb JB. Determination of efficacy of new hemostatic dressings in a model of extremity arterial hemorrhage in swine. J Trauma 2009;67:450-9. [CrossRef]

24. Rall JM, Cox JM, Songer AG, Cestero RF, Ross JD. Comparison of novel hemostatic dressings with QuikClot combat gauze in a standardized swine model of uncontrolled hemorrhage. J Trauma Acute Care Surg 2013;75:S150-6. [CrossRef]

25. Zhang YJ, Gao B, Liu XW. Topical and effective hemostatic medicines in the battlefield. Int J Clin Exp Med 2015;8:10-9.

26. Clay JG, Grayson JK, Zierold D. Comparative testing of new hemostatic agents in a swine model of extremity arterial and venous hemorrhage. Mil Med 2010;175:280-4. [CrossRef]

27. Ward KR, Tiba MH, Holbert WH, Blocher CR, Draucker GT, Proffitt EK, et al. Comparison of a new hemostatic agent to current combat hemostatic agents in a Swine model of lethal extremity arterial hemorrhage. J Trauma 2007;63:276-83. [CrossRef]

28. Kheirabadi BS, Mace JE, Terrazas IB, Fedyk CG, Estep JS, Dubick MA, et al. Safety evaluation of new hemostatic agents, smectite granules, and kaolin-coated gauze in a vascular injury wound model in swine. J Trauma 2010;68:269-78. [CrossRef]

29. Chen YI, Barkun AN. Hemostatic Powders in Gastrointestinal Bleeding: A Systematic Review. Gastrointest Endosc Clin N Am 2015;25:535-52.

30. Barkun AN, Moosavi S, Martel M. Topical hemostatic agents: a systematic review with particular emphasis on endoscopic application in GI bleeding. Gastrointest Endosc 2013;77:692-700. [CrossRef]

31. ASGE Technology Committee, Wong Kee Song LM, Banerjee S, Barth BA, Bhat Y, Desilets D, Gottlieb KT, et al. Emerging technologies for endoscopic hemostasis. Gastrointest Endosc 2012;75:933-7. [CrossRef]
32. Turk S, Malkan UY, Ghasemi M, Hocaoglu H, Mutlu D, Gunes G, et al. Growth inhibitory activity of Ankaferd hemostat on primary melanoma cells and cell lines. SAGE Open Med 2017;5:2050312116689519.

33. Uygun M, Yavuz OY, Uraş İ, Duman İG, Haltaş H, Kömürcü M. Effect of Ankaferd Blood Stopper on muscle healing. Clin Invest Med 2016;39:27526. [CrossRef]

34. Metin B, Yilmaz N, Beyhan YE, Babür C, Sipahi M, Ede H, et al. In Vitro Efficacy of the Ankaferd Galenic Hemostatic Extract as a Germicidal Agent. Iran J Parasitol 2016;11:406-10.

35. Howe N, Cherpelis B. Obtaining rapid and effective hemostasis: Part I. Update and review of topical hemostatic agents. J Am Acad Dermatol 2013;69:659.e1-659.e17. [CrossRef]

36. Takagi T, Tsujimoto H, Torii H, Ozamoto Y, Hagiwara A. Two-layer sheet of gelatin: A new topical hemostatic agent. Asian J Surg 2016. pii: S1015-9584(16)30118-X.

37. Dowling MB, Chaturvedi A, MacIntire IC, Javvaji V, Gustin J, Raghavan SR, et al. Determination of efficacy of a novel alginate dressing in a lethal arterial injury model in swine. Injury 2016;47:2105-9. [CrossRef]

38. Broekema FI, van Oeveren W, Boerendonk A, Sharma PK, Bos RR. Hemostatic action of polyurethane foam with $55 \%$ polyethylene glycol compared to collagen and gelatin. Biomed Mater Eng 2016;27:149-59.

39. Pusateri AE, McCarthy SJ, Gregory KW, Harris RA, Cardenas L, McManus AT, et al. Effect of a chitosan-based hemostatic dressing on blood loss and survival in a model of severe venous hemorrhage and hepatic injury in swine. J Trauma 2003;54:177-82. [CrossRef]

40. Kheirabadi B. Evaluation of topical hemostatic agents for combat wound treatment. US Army Med Dep J 2011:25-37.

41. Lewis KM, Li Q, Jones DS, Corrales JD, Du H, Spiess PE, et al. Development and validation of an intraoperative bleeding severity scale for use in clinical studies of hemostatic agents. Surgery 2017;161:771-81. [CrossRef]

42. TCCC Guidelines for Medical Personnel. Available at: http://cotccc. com/wp-content/uploads/TCCC-Guidelines-for-Medical-Personnel-170131.pdf. Accessed Apr 16, 2017.

\section{DERLEME - ÖZET}

\section{Kanamalara hastane öncesi müdahale sırasında kullanılan topikal hemostatikler: Öncesi ve şimdi}

\section{Dr. H. Erhan Güven}

Sağlık Bilimleri Üniversitesi Gülhane Eğitim ve Araştırma Hastanesi, Genel Cerrahi Anabilim Dalı, Ankara

Kanama sadece yol açtığı volüm defisitine bağlı olarak ölüme neden olan bir sorun değildir. Neden olduğu düzeltilemeyen hipotermi, metabolik asidoz ve koagülasyon bozukluklarıyla da hastaneye yetiştirebilmiş olsa bile yaralının kaybına neden olabilir. Travmaya bağlı olarak boyun, koltuk altı ve kasık bölgeleri gibi turnikeye uygun olmayan lokalizasyonlarda ve ekstremitelerde görülen dışa kanamaların saha şartlarında etkin bir şekilde kontrol altına alınması amacıyla geliştirilen birçok topikal hemostatik ajan mevcuttur. Bu yazıda, farklı etki mekanizmaları ve etkinlikleri olan bu ajanların saha kullanımına uygun olanları ve konu üzerindeki son öneriler irdelenmiştir.

Anahtar sözcükler: Hastane öncesi; kanama; topikal hemostatik.

Ulus Travma Acil Cerrahi Derg 2017;23(5):357-36I doi: 10.5505/tjtes.2017.47279 